\title{
Happiness and the Human Development Index: The Paradox of Australia
}

\author{
David G Blanchflower, Dartmouth College \\ Andrew J Oswald, Warwick University and Harvard University
}

June 2005

Forthcoming in the Australian Economic Review

\begin{abstract}
According to the well-being measure known as the U.N. Human Development Index, Australia now ranks 3rd in the world and higher than all other English-speaking nations. This paper questions that assessment. It reviews work on the economics of happiness, considers implications for policymakers, and explores where Australia lies in international subjective well-being rankings. Using new data on approximately 50,000 randomly sampled individuals from 35 nations, the paper shows that Australians have some of the lowest levels of job satisfaction in the world. Moreover, among the sub-sample of English-speaking nations, where a common language should help subjective measures to be reliable, Australia performs poorly on a range of happiness indicators. The paper discusses this paradox. Our purpose is not to reject HDI methods, but rather to argue that much remains to be understood in this area.
\end{abstract}

Keywords: Well-being, happiness, HDI, macroeconomics.

JEL Classification: E6

\footnotetext{
* This paper was written while the second author was a Wertheim Fellow at Harvard University. For their many helpful suggestions, we thank Ian McDonald and Michael Shields.
} 


\section{Happiness and the Human Development Index: The Paradox of Australia}

\section{Introduction}

What is the appropriate goal of economic and social policy? In a country where people are starving, economic growth is universally viewed as the key objective. Food comes first and philosophising second. As economies get richer, however, they can afford to question the need for further riches. The work stemming from Richard Easterlin's (1974) ideas suggests that they need to do so. Greater wealth does not seem to buy extra happiness. Indeed Blanchflower and Oswald (2004), for example, conclude that Americans' reported happiness has fallen since the early 1970s.

This paper continues a growing tendency for economists to take this issue seriously and to ask whether we should, in one way or another, substitute the goal of Gross National Happiness for the more traditional economist's objective of Gross National Product.

One of the best-known attempts to move away from a simple reliance on GDP as a measure of welfare is the Human Development Index. Published every year by the United Nations, the HDI is a score that amalgamates three indicators: lifespan, educational attainment and adjusted real income. In its latest 2004 Human Development $\underline{\text { Report, }}$ this method of assessing well-being across countries puts Australia at $3^{\text {rd }}$ in the world, and ahead of all the other English-speaking countries. The top-ten countries are:

\section{HDI league table in 2004}

\section{Norway}

2. Sweden

3. Australia

4. Canada

5. Netherlands

6. Belgium 


\section{Iceland \\ 8. USA \\ 9. Japan \\ 10. Ireland}

The HDI, however, is a mechanical criterion. It does not capture the contentment or psychological state of individuals. To do that, some measure of subjective well-being or 'happiness' is required.

\section{Happiness and Economics Research}

Along with other social scientists, economists have begun to study the patterns in subjective well-being data. Some of the main economics references include Easterlin (1974, 1995), Clark and Oswald (1994), Ng (1996, 1997), Kahneman et al (1996), Winkelmann and Winkelmann (1998), Di Tella and MacCulloch (1999), Frey and Stutzer (2000), Di Tella et al (2001, 2003), Blanchflower and Oswald (2004), Helliwell and Putnam (2004), and Frijters, Haisken-DeNew and Shields (2004a, b). In fact, psychologists and sociologists were working on such data sets before most economists paid much attention. See, for instance, the review article by Diener (1984).

Recent findings from such statistical happiness research include the following:

1. For a person, money does buy a reasonable amount of happiness. But it is useful to keep this in perspective. Very loosely, for the typical individual, a doubling of salary makes a lot less difference than life events like marriage.

2. For a nation, things are different. Whole countries -- at least in the West where almost all the research has been done -- do not seem to get happier as they get richer.

3. Happiness is U-shaped in age. Women report higher well-being than men. Two of the biggest negatives in life are unemployment and divorce. Education is associated with high reported levels of happiness even after controlling for income.

4. The structure of a happiness equation has the same general form in each 
industrialized country (and possibly in developing nations, though only a small amount of evidence has so far been collected). In other words, the broad statistical patterns look the same in France, Britain and Australia.

5. There is some evidence that the same is true in panels of people, ie. in longitudinal data. Particularly useful evidence comes from looking at windfalls, like lottery wins.

6. There is adaptation. Good and bad life events wear off -- at least partially -- as people get used to them.

7. Relative things matter a great deal. First, in experiments, people care about how they are treated compared to those who are like them, and in the laboratory will even pay to hurt others to restore what they see as fairness. Second, in large statistical studies, reported well-being depends on a person's wage relative to an average or 'comparison' wage. Third, wage inequality depresses reported happiness in a region or nation (controlling for many variables), but the effect is not large.

Some of these patterns are visible in raw data alone. For example, Di Tella et al (2003) examine the mean life-satisfaction and happiness scores on hundreds of thousands of randomly sampled Europeans and Americans from the 1970s to the 1990s. Approximately $30 \%$ of people describe themselves as very satisfied or very happy. Strong correlations with income, marriage and unemployment are noticeable.

Consistent with point 4 above, similar kinds of patterns are found in Australian data as elsewhere. See, for example, the interesting work of Shields and Wooden (2003), Headey and Wooden (2004), Headey, Muffels and Wooden (2004), and Evans and Kelley (2004), and earlier Australian work cited within them.

\section{Well-being in Australia}

For this paper, we examine the latest data from the International Social Survey Programme (ISSP), which are for the year 2002. Representative ISSP samples of adults are drawn from the populations of 35 nations, including Australia. The set of nations is listed in a later table. 
We use data on the following well-being questions:

- If you were to consider your life in general, how happy or unhappy would you say you are, on the whole? (answered on a 7-point scale)

- All things considered, how satisfied are you with your family life? (on a 7point scale)

- All things considered, how satisfied are you with your main job? (on a 7point scale)

- To what extent do you agree or disagree? My job is rarely stressful (on a 5-point scale)

- How often has the following happened to you during the past three months? I have come home from work too tired to do the chores which need to be done (on a 4-point scale)

If we treat the answers above as measures of well-being, how does Australia fare in a world 'league table'? In particular, it is interesting to ask whether, with the different criteria, the country still conforms to the high position implied by the HDI data.

The answer is that Australia does not show up with markedly high levels of well-being. As a nation, it performs respectably in four categories, and noticeably poorly in one. It is in the top half of the international well-being rankings on happiness, family satisfaction, work stress, and lack-of-tiredness. However, Australia is near the bottom of the international league on job satisfaction levels. Moreover, its rankings among the Englishspeaking nations of the survey -- perhaps the most natural comparison set -- are not notable.

In passing, a small methodological point should be made. In this paper the words 'satisfaction' and 'happiness' will be used largely interchangeably. Whether this creates biases is not currently known. Blanchflower and Oswald (2004), however, show that, where data on both are available, the form of well-being equation is almost identical whichever dependent variable is chosen. 
The international data, for each of our five well-being indicators, are summarised in Table 1. Here a simple arithmetical approach is taken. Mean levels of subjective wellbeing are reported for the different nations. They are produced in the following way. The top ranking on a 7-point scale such as happiness is assigned 7; next down is assigned 6; and so on. Similarly, on a 4-point scale the number 4 is assigned to the highest category; 3 to the next down, and so on. Then the numbers given by each nation's citizens are averaged. This assumes cardinality, which is an unattractive assumption, but later regressions move instead to ordered estimators and the central message is unaltered.

Table 1 reveals that Australians say their happiness level is 5.39 on a scale that runs from a low of one to a high of seven. This first column of Table 1 places Australia as the $12^{\text {th }}$ happiest country in this sample of 35 nations. Austria, by comparison, has a value in column 1 of Table 1 of 5.54; Brazil one of 5.42; and, lower down the table, Switzerland a score of 5.51, and the USA one of 5.52. Although it is unwise to put too much weight on fine differences across countries, and it should be remembered that there will be difficulties of exact translation across languages, according to Table 1 the Australian nation comes in the top half of the international group of 35 on the well-being criteria of columns $1,2,4$, and 5 .

For job satisfaction, the answer is different. Australia comes far down the international league table. Job satisfaction on a seven-point scale averages 5.04 among Australians. Japan and Taiwan are lower, at 4.89 and 4.96, respectively. Apart from this, only East European nations (Bulgaria, Czech Republic, Latvia, Poland, Russia, Slovak Republic) do worse than Australia on the job satisfaction scale.

It is also interesting to treat these well-being answers as providing data for the dependent variables in a variety of regression equations. Such equations allow us to control for the demographic and personal characteristics of the people sampled. This also provides a simple way to test for statistically significant differences by country. 
Tables 2 to 4 set out some basic econometric results. The tables use ordered logit equations to explore the determinants of reported well-being. In each case, an equation is first given for the full data set pooled, and then one for the Australian sub-sample alone. In the Australian columns, we decided to include an income or earnings variable. This was deliberately omitted from the international equations (because it was felt that there was no persuasive way to normalize the measure of income across nations, and because there is a case for studying cross-national well-being without factoring out the influence of real income).

Most variables enter in the familiar way -- see for instance the review in Oswald 1997 -in the All Nations columns in Table 2. Well-being is U-shaped in age. Those widowed, divorced, separated or single show up as markedly less happy than married people. Unemployment and disability have large negative effects. Education is associated with greater well-being. The country dummy variables are of interest. Australia is the omitted, base case. Hence the international dummies indicate whether that nation's reported well-being is greater or lower than Australia's. The string of negatives in the first column of Table 2 indicates that Australian citizens lie towards the middle of the world happiness ranking. Those nations reporting a higher level of happiness, after demographic and personal factors are held constant, are Austria, Brazil, Great Britain, Japan, Mexico, New Zealand, Northern Ireland, the Philippines, Chile, Switzerland and the USA. This evidence contrasts, of course, with the number- 3 position assigned by the Human Development Index.

Satisfaction with family is also studied in Table 2. Australia does respectably: it lies a little above the middle of the international ranking. More precisely, after adjusting for other factors, Australia comes below 11 other nations.

In the international job satisfaction equation of Table 2, Australia continues, as in the raw data of Table 1, to do remarkably poorly. The country dummies that come in below the Australian base category are Bulgaria, Czech Republic, France (though it is not significantly different from zero), Japan, Latvia, Poland, Russia, Slovak Republic, and 
Taiwan. In other words, the approximate pattern is unchanged from the country means. The low well-being levels of East European transition nations has been demonstrated before, in a variety of data sets, by Blanchflower (2001). Table 2 is, overall, quite different from the picture painted by the Human Development Index.

A further set of ordered logits is provided in Table 3. Here Australia enters the pooled international equations around the middle or upper half of the well-being distribution of nations. The first of the variables is for stress at work; the second is for tiredness after returning from work. In each of these, Australia comes fractionally above the middle of the international well-being ranking.

More precisely, among these countries Australia ranks between $11^{\text {th }}$ and $15^{\text {th }}$ in four of the 'all' well-being regression equations, and at $25^{\text {th }}$ on the other 'all' regression for job satisfaction.

\section{The English-Speaking Nations as a Separate Group}

It is probably hazardous to compare one country's happiness answers to another's. Nations have different languages and cultures, and in principle that may cause biases -perhaps large ones -- in happiness surveys. At this point in research on subjective wellbeing, the size of any bias is not known, and there is no accepted way to correct the data, although the literature has made some progress in exploring this issue (for instance, by looking inside a nation like Switzerland at sub-groups with different languages). In the long run, research into ways to difference out country fixed-effects will no doubt be done. The strong well-being performance here of a poor, Spanish-speaking nation like Mexico, therefore, may or may not ultimately be viewed as completely accurate.

One check, however, can be done with the data.

It might be argued that an appropriate comparison set for Australia is the Englishspeaking nations. The main attraction is that this automatically avoids translation 
problems. Moreover, this smaller group of nations has the advantage that they are likely to be more similar in culture and philosophical outlook, and that in turn may reduce other forms of bias in people's answers. Unfortunately, the International Social Survey Programme data for 2002 require us to exclude Canada, which traditionally does well on Human Development Index scoring. However, we do have information on random samples of individuals from Great Britain, Ireland, New Zealand, Northern Ireland, and the USA. Using this group as the yardstick, Australia's well-being levels are again fairly low. Interestingly, from the equations of Tables 2, it can be seen that Australia comes bottom or equal-bottom of the English-speaking nations on happiness, family satisfaction and job satisfaction. It should be noted that people's educational levels and working status are held constant here.

In Table 3, which looks at stress at work and at tiredness after returning home from work, the Australian nation, when compared to the other English-speaking ones, is around the middle of the distribution of well-being. In passing, it should perhaps be noted that a fairly large percentage of Australians are immigrants from non-English-speaking countries with English as their second language, and we are unable to correct for that.

The omission of Canada here is a disadvantage. Nevertheless, it is possible to do a complementary calculation for this country, by using the 2001 ISSP data set, which, although it does not contain the level of detail of the 2002 survey, allows a happiness comparison of the United States, Great Britain, Canada, and New Zealand. Once again, as Table A1 in the Appendix reveals, Australia performs comparatively poorly in a league table of reported happiness (and below all four of these English-speaking nations).

For completeness, separate Australian equations are given for ISSP 2002 data within Tables 2 and 3. These make up the even columns of each table, and are for a sample of approximately 1000 individuals. As might be expected, the general patterns are as in previous research, but the t-statistics are sometimes poorly defined. The quadratic in age works strongly even in the Australian data alone. In general, marital status variables are typically statistically significant and large in size. 


\section{$\underline{\text { V. Issues for the Future }}$}

It is not sensible to view the evidence in this paper as a way of firmly establishing that the HDI measure of human well-being is incorrect. That is not our purpose. Indeed, the underlying philosophy of our work is similar to the one that underpins the UN's index of human development. We believe the goal is to improve upon the traditional narrow economists' focus on real income and growth.

For the wealthy countries of the world, though not the developing countries, our instinct is that it would be a mistake in the twenty-first century to focus excessively on ways to raise the level or growth rate of GDP. The industrialized countries should, in our judgment, use a broader conception of well-being than the height of a pile of dollars. Both HDI data and subjective well-being data lead in that useful direction.

However, the paradox noted here seems of interest. What the paper does is to point to the difficulties of making compatible the Human Development Index approach and modern forms of subjective well-being research. It seems reasonable to believe that they have complementary roles to play (HDI valuably includes a measure of lifespan, for instance, which, at least explicitly, happiness answers cannot) and therefore should be combined.

How exactly a blend can be achieved remains unanswered -- though Veenhoven (1996) has suggested one interesting hybrid of happiness and lifespan and Offer (2003) provides a careful discussion of many different forms of evidence on well-being. But the problem seems an important one to solve.

Methodologically, happiness data, if carefully constructed, are intrinsically more appropriate as an indicator of a nation's mental well-being than any mechanical indicator such as an HDI-style index. Emotion surely ought to play a role in a measure of human well-being. Yet currently not enough is known to be sure how well-being data can supplement or supplant the Human Development Index. 
A key difficulty with HDI-style indicators is that the weights among the different subgoals (education, longevity, GDP) have to be chosen arbitrarily. In principle, happiness equations can provide crucial help here: such regression equations solve out, in effect, for people's utility weights on the different factors that mould the quality of life, many of which do not come with price tags attached. Those calculated weights are captured by the coefficients in an equation of the kind in Table 2, and in the future it might thus be feasible to use them within HDI-style methodology.

Happiness equations thus offer a variety of opportunities. They can tell politicians and others how citizens value the different effects upon well-being of diverse influences such as unemployment, the divorce rate, real income, friendship, traffic jams, crime, health, and much else. If we can learn to exploit the power of statistical happiness equations, it should be possible to make public policy choices in a more coherent way than before.

\section{Conclusions}

This paper studies well-being in Australia. It draws upon ideas from the recent literature on the economics of happiness.

According to the Human Development Index, Australia now ranks 3rd in the world. That places the country above all the other English-speaking nations. This paper raises questions about that assessment. It reviews the new work on happiness economics, considers implications for policymakers, and examines where Australia lies in international subjective well-being rankings. Using new ISSP data on approximately 50,000 randomly sampled individuals from 35 nations, the paper shows that Australia lies close to the bottom of an international ranking of job satisfaction levels. Among a subsample of English-speaking nations, where a common language should help subjective well-being measures to be reliable, Australia performs fairly poorly on a range of happiness indicators. This is a paradox. Our purpose is not to reject HDI methods, but to raise questions, and to argue that much remains to be understood in this important area. 
More broadly, happiness equations have the potential to allow us to value things that are important -- social factors among others -- that do not come with dollar price tags attached. Their structure is still not fully understood. If we can learn to harness them effectively, however, happiness equations offer a remarkable new tool for policymakers. 


\section{References}

Blanchflower, David G. (2001). "Unemployment, Well-being, and Wage Curves in Eastern and Central Europe", Journal of the Japanese and International Economies, 15, 364-402.

Blanchflower, David G. and Oswald, Andrew J. (2004). "Well-being Over Time in Britain and the USA", Journal of Public Economics, 88, 1359-1386.

Clark, Andrew and Oswald, Andrew J. (1994). "Unhappiness and Unemployment", Economic Journal, 104, 648-659.

Diener, Edward (1984). "Subjective Well-Being”, Psychological Bulletin, 93, 542-575.

Di Tella, Rafael, MacCulloch, Robert, and Oswald, Andrew J. (2001). "Preferences over Inflation and Unemployment: Evidence from Happiness Surveys", American Economic Review, 91 (1), 335-42.

Di Tella, Rafael, MacCulloch, Robert, and Oswald, Andrew J. (2003). "The Macroeconomics of Happiness", Review of Economics and Statistics, 85, 809827.

Di Tella, Rafael and MacCulloch, Robert (1999). "Partisan Social Happiness", Harvard mimeo. Forthcoming in the Review of Economic Studies.

Easterlin, Richard A. (1974). "Does Economic Growth Improve the Human Lot? Some Empirical Evidence". In Nations and Households in Economic Growth: Essays in Honour of Moses Abramovitz, (ed. P. A. David and M. W. Reder). New York and London: Academic Press.

Easterlin, Richard A. (1995). "Will Raising the Incomes of All Increase the Happiness of All?", Journal of Economic Behaviour and Organization, 27, 1, 35-48.

Evans, M.D.R. and Kelley, Jonathan (2004). "Effect of Family Structure on Life Satisfaction: Australian Evidence", Melbourne Institute of Applied Economic and Social Research, Working Paper, 24/04.

Frey, Bruno S. and Stutzer, Alois (2000). "Happiness, Economy and Institutions", Economic Journal, 110, 918-938.

Frijters, P.; Haisken-DeNew, J.P.; Shields, M.A. (2004a). "Investigating the Patterns and Determinants of Life Satisfaction in Germany Following Reunification", Journal of Human Resources, 39, 649-674.

Frijters, P.; Haisken-DeNew, J.P.; Shields, M.A. (2004b). "Money Does Matter! Evidence from Increasing Real Income and Life Satisfaction in East Germany Following Reunification", American Economic Review, 94, 730-740.

Headey, Bruce; Muffels, Ruud; and Wooden, Mark (2004). "Money Doesn't Buy Happiness..Or Does it? A Reconsideration Based on the Combined Effects of Wealth, Income and Consumption", Melbourne Institute of Applied Economic and Social Research, Working Paper, 15/04.

Headey, Bruce and Wooden, Mark (2004). "The Effects of Wealth and Income on Subjective Well-being and Ill-Being”, Melbourne Institute of Applied Economic and Social Research, Working Paper, 3/04.

Helliwell, John F. and Putnam, Robert D. (2004). "The Social Context of Well-being', Phil. Trans. R. Soc. Lond. B, 359, 1435-1446. 
Kahneman, Daniel; Wakker, Peter and Rakesh Sarin, (1997). "Back to Bentham? Explorations of Experienced Utility", Quarterly Journal of Economics, 112, 375406.

Ng, Yew-Kwang (1996). "Happiness Surveys: Some Comparability Issues and an Exploratory Survey Based on Just Perceivable Increments", Social Indicators Research, 38, 1-27.

$\mathrm{Ng}$, Yew-Kwang (1997). "A Case for Happiness, Cardinalism, and Interpersonal Comparability", Economic Journal, 107, 1848-1858.

Offer, Avner (2003). "Economic Welfare Measurement and Human Well-being", in Paul A. David and Mark Thomas (eds.), The Economic Future in Historical Perspective (Oxford: Oxford University Press for the British Academy, 2003), 371-399.

Oswald, Andrew J. (1997). "Happiness and Economic Performance", Economic Journal, $107,1815-1831$.

Shields, Mike and Wooden, Mark (2003). "Investigating the Role of Neighbourhood Characteristics in Determining Life Satisfaction", Melbourne Institute of Applied Economic and Social Research, Working Paper, 24/03.

Veenhoven, Ruut (1996). "Happy Life-Expectancy: A Comprehensive Measure of Quality-of-Life in Nations", Social Indicators Research, 39, 1-58.

Winkelmann, Liliana and Winkelmann, Rainer (1998). "Why are the Unemployed so Unhappy?", Economica, 65(257), 1-15. 
Table 1: International Well-being Levels in 2002

Australia

Austria

Brazil

Bulgaria

Cyprus

Czech Republic

Denmark

Finland

Flanders

France

Germany East

Germany West

Great Britain

Hungary

Ireland

Israel Jews

Japan

Latvia

Mexico

Netherlands

New Zealand

Northern Ireland

Norway

Philippines

Poland

Portugal

Republic of Chile

Russia

Slovak Republic

Slovenia

Spain

Sweden

Switzerland

\section{Happiness Family satisfaction}

5.62
5.80
5.31
4.88
5.54
5.14
5.76
5.43
5.47
5.33
5.50
5.56
5.62
5.30
5.81
5.71
5.52
4.96
5.96
5.50
5.60
5.74
5.55
5.61
5.37
5.44
5.81
4.99
5.06
5.55
5.48
5.55
5.73

\section{Job satisfaction}

$$
5.04
$$

5.51

5.11
4.75

5.36

4.92

5.42

5.12

5.22

5.07
5.14

5.27

5.06

5.11

5.41

5.19

4.89

4.82

5.80

5.12

5.14

5.31

5.23
5.33

4.94

4.94
5.17

5.16

4.89

4.96

5.17

5.05

5.17

5.61
Work stress

Not tired

\begin{tabular}{ll}
3.43 & 2.53 \\
3.55 & 2.07 \\
2.82 & 2.68 \\
3.04 & 2.86 \\
3.63 & 2.27 \\
3.51 & 2.45 \\
3.06 & 2.39 \\
3.41 & 2.30 \\
3.52 & 2.40 \\
3.68 & 2.64 \\
3.83 & 2.34 \\
3.80 & 2.46 \\
3.55 & 2.68 \\
3.04 & 2.73 \\
3.22 & 2.37 \\
3.15 & 2.81 \\
3.38 & 1.90 \\
3.47 & 2.62 \\
2.70 & 2.53 \\
3.30 & 2.42 \\
3.49 & 2.48 \\
3.45 & 2.46 \\
3.59 & 2.54 \\
3.21 & 2.41 \\
3.09 & 2.75 \\
3.10 & 2.47 \\
3.07 & 2.89 \\
2.88 & 2.82 \\
3.33 & 2.88 \\
3.47 & 2.52 \\
3.23 & 2.70 \\
3.58 & 2.53 \\
3.07 & 2.01 \\
& \\
\hline
\end{tabular}


Taiwan

United States

$\mathrm{N}$

5.19

5.52
45800

5.38

5.67

44936

4.96

5.34

25197

Source: ISSP 2002.

Notes: columns 3-5 are for workers only.
2.99

3.25

24796
2.13

2.71

24829 


\section{Notes on Table 1's Questions}

Questions were as follows: note that apart from column 4 all numbers have been reversed.

In column 1 , the number $7=$ 'completely happy'. In column 4 , the number $5=$ 'strongly disagree that my job is rarely stressful', so a positive number means the worker is more stressed.

Column 1. If you were to consider your life in general, how happy or unhappy would you say you are, on the whole?

1. Completely happy

2. Very happy

3. Fairly happy

4. Neither happy nor unhappy

5. Fairly unhappy

6. Very unhappy

7. Completely unhappy

Column 2. All things considered, how satisfied are you with your family life?

1. Completely satisfied

2. Very satisfied

3. Fairly satisfied

4. Neither satisfied nor dissatisfied

5. Fairly dissatisfied

6. Very dissatisfied

7. Completely dissatisfied

Column 3. All things considered, how satisfied are you with your (main) job?

1. Completely satisfied

2. Very satisfied

3. Fairly satisfied

4. Neither satisfied nor dissatisfied

5. Fairly dissatisfied

6 . Very dissatisfied

7. Completely dissatisfied

Column 4. My job is rarely stressful.

1. Strongly agree

2. Agree

3. Neither agree nor disagree

4. Disagree

5. Strongly disagree

Column 5. How often has each of the following happened to you during the past three months? I have come home from work too tired to do the chores which need to be done.

1. Several times a week

2. Several times a month

3. Once or twice

4. Never 
Table 2 International and Australian Well-being Equations (Ordered logits)

\begin{tabular}{|c|c|c|c|c|c|c|}
\hline \multirow[b]{3}{*}{ Age } & \multicolumn{2}{|c|}{ Happiness } & \multicolumn{2}{|c|}{ Family satisfaction } & \multicolumn{2}{|c|}{ Job satisfaction } \\
\hline & All & Australia & All & Australia & All & Australia \\
\hline & $-.0703(19.50)$ & $-.0901(3.26)$ & $-.0674(18.54)$ & $-.1000(3.35)$ & $-.0298(4.72)$ & $-.0413(1.16)$ \\
\hline $\mathrm{Age}^{2}$ & $.0006(17.50)$ & $.0010(3.64)$ & $.0006(17.06)$ & $.0010(3.54)$ & $.0004(5.93)$ & .0007 (1.79) \\
\hline Male & $.0493(2.56)$ & $-.0007(0.01)$ & $.1146(5.91)$ & $.1204(0.91)$ & $-.0218(0.85)$ & $.3374(2.04)$ \\
\hline Widowed & $-.9550(24.70)$ & $-.4749(1.53)$ & $-.9636(24.68)$ & $-.4755(1.29)$ & & \\
\hline Divorced & $-.9410(24.79)$ & $-.3237(1.44)$ & $-1.1642(29.60)$ & $-.7680(3.23)$ & & \\
\hline Separated & $-1.0734(17.08)$ & $-.4608(1.43)$ & $-1.3725(21.91)$ & $-.5087(1.66)$ & & \\
\hline Single & $-.7061(26.42)$ & $-.7679(3.73)$ & $-.8538(31.22)$ & $-1.0024(4.21)$ & & \\
\hline Part-time worker & $-.0263(0.79)$ & $.1338(0.75)$ & $-.0062(0.19)$ & $.2965(1.64)$ & $-.1371(3.35)$ & $-.1632(0.72)$ \\
\hline Employed<part-time & $-.0809(1.14)$ & & $-.0551(0.77)$ & & $-.2096(2.25)$ & $\mathrm{n} / \mathrm{a}$ \\
\hline Helping family member & $.0017(0.01)$ & & $-.0642(0.55)$ & & & \\
\hline Unemployed & $-.5856(14.10)$ & $-1.1429(1.97)$ & $-.4149(9.98)$ & $-.9352(1.81)$ & & \\
\hline Student & $.1170(2.53)$ & $-.3938(0.72)$ & $.0869(1.84)$ & $.2477(0.47)$ & & \\
\hline Retired & $-.0919(2.61)$ & $-.0330(0.16)$ & $-.0866(2.44)$ & $-.1093(0.50)$ & & \\
\hline Housewife & $-.0047(0.14)$ & $-.3780(1.38)$ & $-.0204(0.59)$ & $-.3613(1.32)$ & & \\
\hline Disabled & $-.5060(7.23)$ & $\mathrm{n} / \mathrm{a}$ & $-.3271(4.64)$ & $\mathrm{n} / \mathrm{a}$ & & \\
\hline OLF & $-.3200(5.28)$ & $-.9971(2.44)$ & $-.3245(5.37)$ & $-.8714(1.92)$ & & \\
\hline Lowest qualification & $-.0100(0.24)$ & $-1.8841(1.71)$ & $.0148(0.36)$ & $-1.0859(1.04)$ & $.0225(0.30)$ & \\
\hline Above lowest & $.1600(3.75)$ & $-1.2259(1.24)$ & $.1637(3.90)$ & $-1.0787(1.16)$ & $.1517(2.09)$ & \\
\hline Higher secondary & $.2250(5.30)$ & $-1.5188(1.52)$ & $.1991(4.77)$ & $-1.4061(1.50)$ & $.2528(3.51)$ & \\
\hline Above higher secondary & $.2800(6.17)$ & $-1.2515(1.25)$ & $.2043(4.56)$ & $-1.2172(1.29)$ & $.3875(5.22)$ & \\
\hline University degree & $.3844(8.53)$ & $-1.2466(1.26)$ & .2177 (4.89) & $-1.3615(1.46)$ & $.4648(6.36)$ & \\
\hline Family income $* 10^{6}$ & & $-.5250(0.23)$ & & $-.6590(0.03)$ & & \\
\hline Earnings $* 10^{5}$ & & & & & & $.5700(2.11)$ \\
\hline Union member & & & & & $-.0981(3.14)$ & $-.3580(2.11)$ \\
\hline Self-employed & & & & & $.3928(10.68)$ & $.5417(2.45)$ \\
\hline Public sector & & & & & $.2196(7.19)$ & $.0896(0.50)$ \\
\hline Hours of work & & & & & $.0013(1.19)$ & $.0031(0.41)$ \\
\hline Austria & $.4134(6.12)$ & & $.5042(7.14)$ & & $.9860(10.59)$ & \\
\hline Brazil & $.4423(6.21)$ & & $-.3330(4.58)$ & & $.1100(1.09)$ & \\
\hline Bulgaria & $-1.6117(20.45)$ & & $-1.3526(16.66)$ & & $-.6800(5.77)$ & \\
\hline Cyprus & $-.0923(1.15)$ & & $-.1043(1.32)$ & & $.6732(6.82)$ & \\
\hline Czech Republic & $-.7606(10.11)$ & & $-.8599(11.23)$ & & $-.2520(2.02)$ & \\
\hline Denmark & $-.1206(1.59)$ & & $.3782(4.89)$ & & $.6407(6.54)$ & \\
\hline
\end{tabular}




\section{Finland \\ Flanders}

Germany East

Germany Wes

Great Britain

Hungary

Ireland

Israel Jews

Japan

Latvia

Mexico

Netherlands

New Zealand

Northern Ireland

Norway

Philippines

Poland

Portugal

Republic of Chile

Russia

Slovak Republic

Slovenia

Spain

Sweden

Switzerland

Taiwan

United States

$\begin{array}{lr}\text { Cut_1 } & -8.2572 \\ \text { Cut_2 } & -6.7028 \\ \text { Cut_3 } & -5.2755 \\ \text { Cut_4 } & -3.7093 \\ \text { Cut_5 } & -1.5908 \\ \text { Cut_6 } & .3909\end{array}$

Pseudo $\mathrm{R}^{2}$

$-.3441(4.45)$
$-.3725(4.99)$
$-.3069(4.44)$
$-.6619(6.40)$
$-.4331(5.38)$
$.2300(3.34)$
$-.5937(7.39)$
$-.0303(0.41)$
$-.2289(2.94)$
$.2927(3.67)$
$-1.1849(14.91)$
$.5739(7.55)$
$-.2255(3.03)$
$.2672(3.28)$
$.6129(7.63)$
$-.1849(2.53)$
$.1290(1.62)$
$-.7831(10.41)$
$-.3840(4.83)$
$.4732(6.43)$
$-1.0989(15.46)$
$-.9461(12.17)$
$-.4804(6.17)$
$-.2662(4.07)$
$-.2381(3.02)$
$.3382(4.33)$
$-.3835(5.56)$
$.4103(5.37)$

$-.3885(4.88)$

$-.2780(3.63)$

$-.4630(6.44)$

$-.1027(0.97)$

$-.0498(0.60)$

$1820(2.56)$

$-.2957(3.58)$

$4111(5.34)$

$1697(2.16)$

$-.2716(3.38)$

-1.1685 (14.17)

8242 (10.76)

$-.1744(2.27)$

.1097 (1.31)

$.5501(6.64)$

$-.0303(0.41)$

$.0789(0.98)$

-.3885 (5.04)

$-.2197(2.74)$

$.5756(7.76)$

$-1.0479(14.07)$

$-.8532(10.61)$

$-.1485(1.85)$

-.2237 (3.34)

$.0492(0.60)$

.2964 (3.72)

-.4795 (6.87)

.3588 (4.53)

-9.2735
-8.1644
-6.5476
-5.3149
-3.1527
-.6158

$-7.3819$

$-6.2914$

$-5.0844$

$-3.9170$

$-2.0392$

$-.1408$

.0443
$.0783(0.77)$

$.2387(2.43)$

$-.0254(0.29)$

$.1030(0.71)$

$.3980(3.61)$

$.0568(0.63)$

$.0207(0.18)$

$.6212(6.09)$

.1929 (1.88)

$-.2349(2.21)$

$-.5950(5.51)$

$1.4400(14.27)$

.1799 (1.86)

$.1365(1.31)$

$.4835(4.31)$

$.2440(2.63)$

$.5526(5.16)$

$-.3111(2.95)$

$.1527(1.40)$

$3787(3.71)$

$-.4940(5.14)$

$-.0796(0.75)$

$.1676(1.54)$

$.0040(0.05)$

.2059 (2.06)

$.9087(9.15)$

$-.2220(2.47)$

.5740 (5.76)

$-8.8913$

$-7.9202$

$-6.5198$

$-5.6934$

$-3.8569$

$-1.8244$

.0237
$-4.7118$

$-3.4606$

$-2.2701$

1.2873

.6130

2.5051

.0222
$-3.8968$

$-2.2564$

$-.7243$

1.9525

4.1828

.0195 
Source: ISSP 2002. Notes: t-statistics are in parentheses. The excluded-variable categories are Australia, married, full-time, and no formal qualifications.

Columns 1, 3 and 5 pool together the nations ('All' means all countries combined). Columns 2, 4 and 6 are for the Australian sample alone. Columns 5 and 6 are for workers only. The earnings variable is deliberately not included in the All columns; this is partly because there is no straightforward way to normalize income internationally. 
Table 3 Further International and Australian Equations (Ordered Logits)

\begin{tabular}{|c|c|c|c|c|}
\hline & Work stre & & Not ti & \\
\hline & All & Australia & All & Australia \\
\hline Age & $.0410(6.54)$ & $.0337(0.95)$ & $.0221(3.49)$ & $-.0261(0.72)$ \\
\hline $\mathrm{Age}^{2}$ & $-.0005(7.30)$ & $-.0007(1.45)$ & $-.0003(5.05)$ & $.0001(0.22)$ \\
\hline Male & $-.1766(6.91)$ & $-.3523(2.11)$ & $-.5004(19.46)$ & $-.9311(5.42)$ \\
\hline Part-time worker & $-.0936(2.27)$ & $.3570(1.57)$ & $-.0575(1.41)$ & $.4009(1.74)$ \\
\hline Employed<part-time & $.3636(3.90)$ & $\mathrm{n} / \mathrm{a}$ & & $-.0659(0.68)$ \\
\hline Lowest qualification & $-.0131(0.17)$ & $1.8802(1.01)$ & $-.3616(4.68)$ & $\mathrm{n} / \mathrm{a}$ \\
\hline Above lowest & $.1157(1.55)$ & $1.8861(1.15)$ & $-.4810(6.58)$ & $-.9400(1.09)$ \\
\hline Higher secondary & $.2362(3.17)$ & $1.9143(1.16)$ & $-.4711(6.50)$ & $-.7598(0.86)$ \\
\hline Above higher secondary & $.3643(4.78)$ & $2.2489(1.36)$ & $-.3573(4.80)$ & $-.5544(0.63)$ \\
\hline University degree & $.5721(7.57)$ & $2.3817(1.45)$ & $-.2709(3.69)$ & $-.4378(0.50)$ \\
\hline Earnings $* 10^{5}$ & & $.6670(2.44)$ & & $.2200(0.81)$ \\
\hline Union member & $.1451(4.68)$ & $.3281(1.92)$ & $.1444(4.64)$ & $.1554(0.91)$ \\
\hline Self-employed & $-.0909(2.46)$ & $-.2449(1.14)$ & $-.1742(4.67)$ & $-.0269(0.12)$ \\
\hline Public sector & $-.0289(0.95)$ & $.3251(1.82)$ & $-.0461(1.52)$ & $.0173(0.10)$ \\
\hline Hours of work & $.0192(16.01)$ & $.0249(3.19)$ & $.0217(17.89)$ & $.0485(6.02)$ \\
\hline Austria & $.1716(1.86)$ & & -1.0137 (11.09) & \\
\hline Brazil & $-1.0182(8.85)$ & & $.0175(0.17)$ & \\
\hline Bulgaria & $-.7493(6.29)$ & & $.4481(3.84)$ & \\
\hline Cyprus & $.0874(0.91)$ & & $-.5539(5.89)$ & \\
\hline Czech Republic & $.0231(0.19)$ & & $-.2060(1.73)$ & \\
\hline Denmark & $-.7703(7.55)$ & & $-.4071(4.26)$ & \\
\hline Finland & -.1108 (1.09) & & $-.5107(5.22)$ & \\
\hline Flanders & $.0048(0.05)$ & & $-.2901(2.97)$ & \\
\hline France & $.3865(4.27)$ & & $.0506(0.59)$ & \\
\hline Germany East & $.5414(3.77)$ & & $-.4769(3.33)$ & \\
\hline Germany West & $.6169(5.58)$ & & $-.2002(1.85)$ & \\
\hline Great Britain & $.2000(2.24)$ & & $.1526(1.76)$ & \\
\hline Hungary & $-.7546(6.60)$ & & $.2458(2.09)$ & \\
\hline Ireland & $-.3599(3.56)$ & & $-.3312(3.35)$ & \\
\hline Israel Jews & $-.5358(5.40)$ & & $.5063(5.12)$ & \\
\hline Japan & $.0650(0.57)$ & & $-1.3723(12.51)$ & \\
\hline Latvia & $-.1817(1.76)$ & & $.0413(0.40)$ & \\
\hline Mexico & $-1.1006(10.74)$ & & $-.1033(1.04)$ & \\
\hline Netherlands & $-.2264(2.39)$ & & $-.1063(1.12)$ & \\
\hline New Zealand & $.0586(0.58)$ & & $-.1632(1.64)$ & \\
\hline Northern Ireland & $.1442(1.30)$ & & $-.1363(1.25)$ & \\
\hline Norway & $.0231(0.25)$ & & $-.1119(1.24)$ & \\
\hline Philippines & $-.3217(3.14)$ & & $-.2251(2.21)$ & \\
\hline Poland & $-.6645(6.28)$ & & $.2405(2.32)$ & \\
\hline Portugal & $-.5022(4.72)$ & & $-.1741(1.63)$ & \\
\hline Republic of Chile & $-.6208(6.16)$ & & .4455 (4.59) & \\
\hline Russia & $-1.0524(11.37)$ & & $.3629(3.92)$ & \\
\hline Slovak Republic & $-.2355(2.29)$ & & $.5037(5.03)$ & \\
\hline Slovenia & $-.0466(0.44)$ & & $-.1728(1.60)$ & \\
\hline Spain & $-.2852(3.24)$ & & .3237 (3.64) & \\
\hline Sweden & $.1237(1.27)$ & & $-.0971(1.01)$ & \\
\hline Switzerland & $-.5125(5.17)$ & & $-.9512(9.57)$ & \\
\hline Taiwan & $-.8089(8.97)$ & & $-1.0396(11.50)$ & \\
\hline United States & $-.3984(4.08)$ & & $.2059(2.14)$ & \\
\hline Cut_1 & -1.3182 & .3943 & -1.2450 & -2.4872 \\
\hline Cut_2 & .5694 & 2.5403 & .3333 & .1425 \\
\hline Cut_3 & 1.3224 & 3.3475 & 1.7837 & 1.6938 \\
\hline Cut_4 & 3.1599 & 5.3202 & & \\
\hline Pseudo $\mathrm{R}^{2}$ & .0290 & .0425 & .0387 & .0570 \\
\hline
\end{tabular}


Source: ISSP 2002. Notes: t-statistics are in parentheses. The excluded-variable categories are Australia, married, full-time, and no formal qualifications. Data are for workers only. See also the notes to Table 2. 


\section{Appendix}

\section{Table A1: Country Dummies from an Ordered Logit Happiness Equation for an Earlier Year - ISSP 2001}

$\begin{array}{lc}\text { Germany-West } & -.2184(2.44) \\ \text { Germany-east } & -.5747(5.00) \\ \text { Great Britain } & .2428(2.73) \\ \text { United States } & .6140(7.37) \\ \text { Austria } & .1900(2.20) \\ \text { Hungary } & -.9692(12.23) \\ \text { Italy } & -1.1323(12.45) \\ \text { Norway } & -.2114(2.67) \\ \text { Czech Republic } & -.8472(10.03) \\ \text { Slovenia } & -.9566(10.68) \\ \text { Poland } & -.8361(9.87) \\ \text { Russia } & -3.0329(39.62) \\ \text { New Zealand } & .4845(5.81) \\ \text { Canada } & .2756(3.22) \\ \text { Philippines } & -.1226(1.41) \\ \text { Israel Jews } & -.6755(7.53) \\ \text { Israel Arabs } & -1.2473(6.56) \\ \text { Japan } & -.2094(2.45) \\ \text { Spain } & -.5237(6.28) \\ \text { Latvia } & -1.8377(20.48) \\ \text { France } & -.0538(0.66) \\ \text { Cyprus } & -1.4289(15.78) \\ \text { Chile } & .3456(4.26) \\ \text { Denmark } & -.0175(0.19) \\ \text { Switzerland } & .5971(6.87) \\ \text { Brazil } & 1.2960(15.14) \\ \text { Finland } & -.6422(7.64) \\ & \\ \text { _cut1 } \text { cut2 } & -5.7125 \\ \text { _cut3 } & -3.6388 \\ \text { N } & -.5376 \\ \text { Pseudo R2 } & \\ \text { Log likelihood } & 29242 \\ & .1112 \\ & -28016 \\ & \\ \text { Swand } & \end{array}$

Source: International Social Survey Programme 2001.

Notes: t-statistics are in parentheses. Australia is the excluded-country category. Answers here are on a 4point happiness scale: not at all happy, not very happy, fairly happy, very happy. Controls in the equation are age and age squared, gender, years of education, 11 workforce status dummies, and 5 marital status dummies. 